\title{
Traumatic ulcerative granuloma with stromal eosinophilia: a series of four cases with review of literature
}

\author{
Sangita Sharma Mehta ${ }^{1}$, Rajeshwari K Muthusamy ${ }^{1}$
}

${ }^{I}$ Department of Pathology, Kovai Medical Center And Hospital, Coimbatore, India

\section{Keywords: \\ Eosinophilic ulcer; Oral mucosa; \\ Tongue; \\ Traumatic ulcer; \\ Ulcerative granuloma;}

\begin{abstract}
Most of the oral ulcers are traumatic in origin due to sharp tooth and self bite. Traumatic ulcerative granuloma with stromal eosinophilia is a chronic benign lesion of the oral mucosa with uncertain histogenesis. Trauma was proposed to be an inciting factor.

A series of four cases of Traumatic Ulcerative Granuloma with Stromal Eosinophilia in the lateral borders of the tongue were analyzed regarding oral hygiene, sharp tooth, clinical presentation, histology, and follow-up. The lesion manifests as a small solitary ulcer with induration in the oral mucosa mimicking malignancy. Histology revealed ulcers with exudate and granulation tissue with dense polymorphous infiltrate rich in eosinophils. Infiltrate extends down in between the skeletal muscle fibers and salivary gland lobules. A sharp tooth was found to be the inciting factor in a proportion of cases. Histopathological examination is mandatory to confirm the diagnosis and to exclude malignancy and other eosinophil rich disorders.
\end{abstract}

\section{Correspondence:}

Dr. Rajeshwari K Muthusamy

Department of Pathology

Kovai Medical Center And Hospital, Coimbatore, India

ORCID ID: 0000-0001-6007-4683

Email:drrajeshwarikm@kmchhospitals.com

Received : June $25^{\text {th }} 2020$; Accepted : September $22^{\text {nd }} 2020$

Citation: Mehta SS, Muthusamy RK. Traumatic ulcerative granuloma with stromal eosinophilia a series of four cases with review of literature. J Pathol Nep 2020;10:1779-82. DOI: 10.3126/jpn. v10i2.24596

Copyright: This is an open-access article distributed under the terms of the Creative Common Attribution 4.0 International License, which permits unrestricted use, distribution, and reproduction in any medium, provided the original author and source are credited.

\section{INTRODUCTION}

Traumatic ulcerative granuloma with stromal eosinophilia, also known as traumatic granuloma, eosinophilic ulcer of the oral mucosa, and atypical histiocytic granuloma, is a chronic benign self-limiting lesion of the oral mucosa which can mimic malignancy clinically. ${ }^{1}$ The etiology and pathogenesis are unclear although trauma was proposed to have a causative role. ${ }^{2}$ Popoff in 1956 was the first to report this lesion in adults. A similar lesion in infants was named Riga- Fede disease. ${ }^{3,4}$

\section{CASE REPORT}

A 59-year-old female came to the hospital with a history of non-healing ulcer in the tongue for the last 3 months with mild pain. There was no significant history. The extraoral examination was non contributory. Intraoral examination showed poor oral hygiene with caries (left lower premolar), sharp upper canine, and a solitary ulcer in the left lateral border of the tongue with minimal induration and everted margins. A provisional diagnosis of the chronic ulcer was 


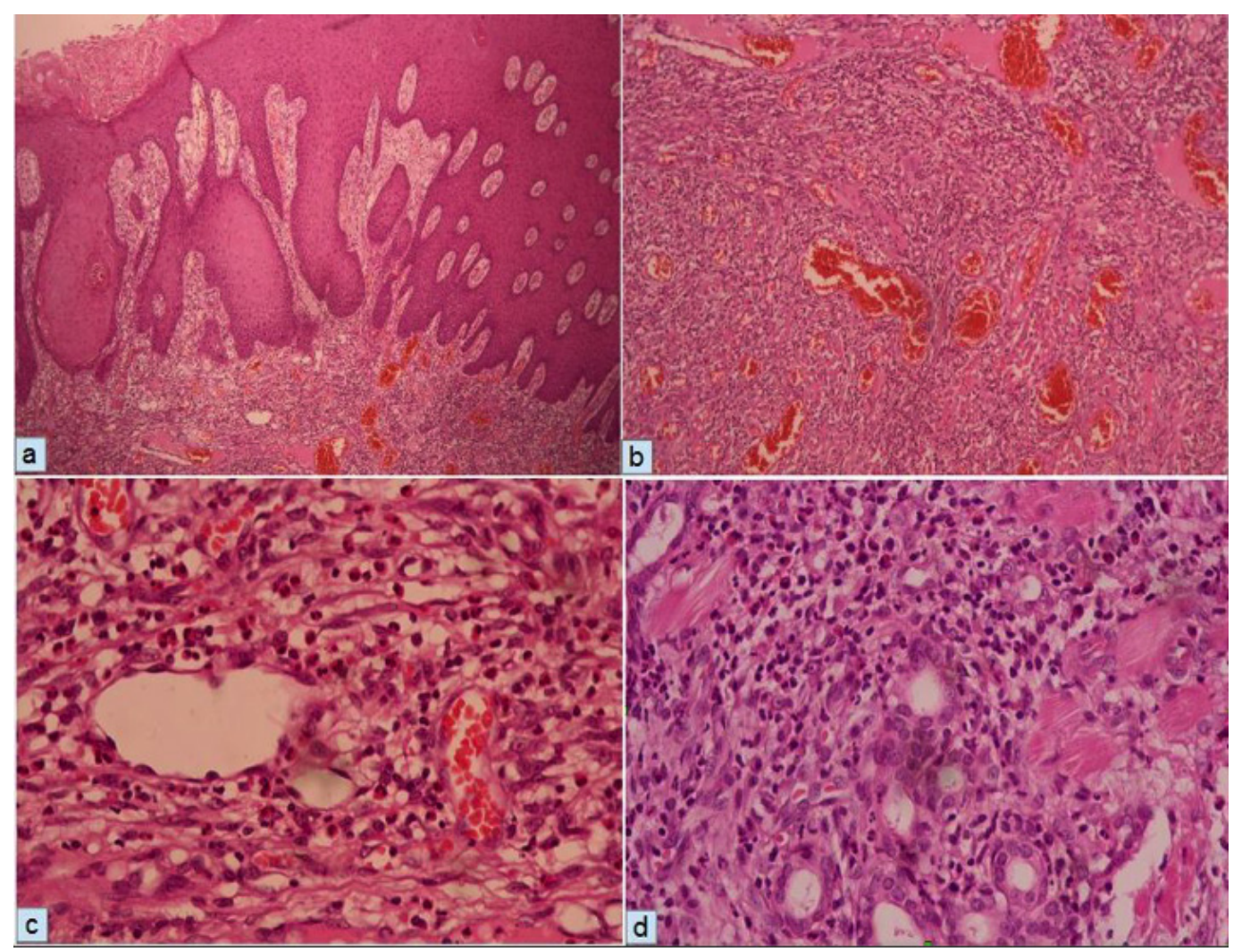

Figure 1a: Hyperplastic epidermis adjacent to the ulcer with inflammatory infiltrate in the stroma (HE stain; X100). 1b: Stroma with dense polymorphous inflammatory cell infiltrate and many vessels (HE stain; X100). 1c: High power image showing polymorphous infiltrate rich in eosinophils (HE stain; X400). 1d: High power image showing dense polymorphous infiltrate infiltrating between skeletal muscle fibers and salivary gland lobules (HE stain; X400).

made and she was prescribed a course of antibiotics. Her blood investigations revealed peripheral eosinophilia. The symptoms did not improve and the ulcer was not healing. Hence wide excision of the ulcer was done to exclude malignancy. She was not willing to remove the caries tooth and the sharp tooth.

Histopathology of the lesion showed squamous mucosa with hyperplastic changes and ulceration covered with abundant purulent exudate (fig. 1a). Granulation tissue beneath showed proliferating capillaries with prominent endothelial cells and a dense polymorphous infiltrate comprising of many eosinophils (fig. 1b,c) and histiocytes. There was no evidence of malignancy or dysplasia. Inflammatory infiltrate was extending down to involve the skeletal muscle and mucous salivary glands (fig. $1 \mathrm{~d}$ ). A diagnosis of Traumatic Ulcerative Granuloma with Stromal Eosinophilia (TUGSE) was made. She came up four months later with the recurrence of a similar-appearing lesion in the tongue of size $0.5 \mathrm{~cm}$. She was advised for tooth extraction but she denied it. We had three other similar cases, tabulated with relevant clinical findings (Table 1 ).

\begin{tabular}{|c|c|c|c|c|c|c|c|c|}
\hline Case & Age/Sex & $\begin{array}{l}\text { Site of } \\
\text { Ulcer }\end{array}$ & Duraation & Sharp tooth & $\begin{array}{c}\text { Other clinical } \\
\text { details }\end{array}$ & $\begin{array}{c}\text { Sharp } \\
\text { tooth extra- } \\
\text { tion }\end{array}$ & Recurrence & $\begin{array}{c}\text { Follow up } \\
\text { period }\end{array}$ \\
\hline 1 & $59 \mathrm{~F}$ & $\begin{array}{l}\text { Left lateral } \\
\text { border } \\
\text { (LB) } \\
\text { of tongue }\end{array}$ & 2 months & Present & $\begin{array}{l}\text { Caries tooth } \\
\text { and } \\
\text { Peripheral } \\
\text { blood } \\
\text { eosinophilia }\end{array}$ & No & Yes & 4 months \\
\hline 2 & $57 \mathrm{~F}$ & $\begin{array}{l}\text { Right LB } \\
\text { of tongue }\end{array}$ & 1 month & Present & Nil & Yes & No & 12 months \\
\hline 3 & $59 \mathrm{M}$ & $\begin{array}{l}\text { Right LB } \\
\text { of tongue }\end{array}$ & 2 weeks & No & $\begin{array}{c}\text { Poor oral } \\
\text { hygiene, } \\
\text { Hypothyroid }\end{array}$ & & No & 42 months \\
\hline 4 & $61 \mathrm{~F}$ & $\begin{array}{l}\text { Right LB } \\
\text { of tongue }\end{array}$ & 2 months & No & $\begin{array}{l}\text { Tobacco } \\
\text { Chewer }\end{array}$ & & No & 25 months \\
\hline
\end{tabular}




\section{DISCUSSION}

Traumatic ulcerative granuloma with stromal eosinophilia is a unique and distinct delineated entity of the oral mucosa by Shapiro and Juhlin, ${ }^{5}$ although the lesion was described in children by Riga in 1881 and Fede in 1890 , and in adults, by Popoff in $1956{ }^{3,5}$ It is a lesion of uncertain pathogenesis and treatment. The most frequent presentation is that of an ulcer, often single, varying in size from 0.3 to $2 \mathrm{~cm}$ in diameter. with mild pain, and everted borders with induration mimicking malignancy. ${ }^{6}$ The common site of involvement in the tongue, the other sites which could be involved are buccal mucosa, lip, palate, and gingiva. ${ }^{1,2,7}$ The duration of the lesion varies ranging from several weeks to months. They are selflimiting lesions but take a long time to heal without many recurrences unless the causative factors like a sharp tooth are persisting. Any ulcer which does not heal for more than 2 weeks alerts the clinician to exclude the possibility of malignancy. ${ }^{8}$ It exhibits a slight female predominance with bimodal distribution and a peak incidence between the sixth and seventh decades of life. ${ }^{1}$

In our cases, solitary non-healing ulcers were seen in all with a duration of two weeks to three months and sizes ranging from 0.7 to $1.5 \mathrm{~cm}$. The tongue was involved in all, predominantly the right side ( $3 / 4$ patients). Trauma due to a sharp tooth was the inciting cause in two patients, while the other 2 have neither history of trauma nor a sharp tooth. Peripheral eosinophilia and chronic tobacco chewing were noted in one of the patients. All these patients were in the sixth decade, with female preponderance as described in the literature. There was no lymphadenopathy. The ulcers were small with a yellow base, everted or rolled out margins, and revealed mild induration. It was firm and tender on palpation.

Velez et al considered trauma as the initiative factor for the development of TUGSE. ${ }^{9}$ Mucosal breakdown following trauma could lead to the entry of viral or toxic agents into the underlying tissue provoking an inflammatory response with eosinophils. ${ }^{9}$ Tongue being the most common location (as also seen in our series) can be traumatized easily by a sharp tooth or during mastication and definite history of trauma in some of the reported cases agree with this hypothesis. These eosinophils degranulate and release toxic proteins such as Major Basic Protein (MBP), Eosinophilic cationic Protein (ECP), Eosinophil Peroxidase (EPO), and cytokines such as Tumor Necrosis Factor (TNF) enhancing tissue damage. ${ }^{10}$ Elovic et al showed a lack of synthesis of Transforming Growth Factor (TGF) by eosinophils which explains the delayed healing of ulcer characteristics of TUGSE. ${ }^{11}$ As all traumatic ulcers do not show an eosinophil-rich inflammatory infiltrate, alternate theories were suggested such as possible interaction with mast cells, the role of cytokines and chemotactic factors
2, and cell-mediated immunity. ${ }^{12}$ However histogenesis is still uncertain and controversial.

The clinical differential diagnosis of ulcerative lesions of the tongue, in particular, includes traumatic ulcers, infections such as syphilis, and tumors like squamous cell carcinoma, lymphoma, and rarely metastasis. ${ }^{13}$ Eosinophilic ulcer of oral mucosa has to be differentiated from eosinophil rich disorders like Angiolymphoid hyperplasia with eosinophilia, Kimura's disease, Langerhans cell Histiocytosis, contact allergy, drug reactions, and Immunobullous disorders. All these have been excluded in our cases with proper clinicopathological correlation. In Angiolymphoid hyperplasia with eosinophilia, mucosal involvement is rare. The lesions show pronounced vascular proliferation with plump endothelial cells and lymphoid follicles. ${ }^{2}$ Kimura's disease is a chronic inflammatory disorder with rare oral mucosal involvement, lack of histiocytic infiltrate despite having prominent inflammatory infiltrate, and eosinophilic folliculolysis of germinal centers. ${ }^{2}$

Many different treatment approaches have been reported in the literature e.g. wait and watch policy, mouthwashes, antibiotics, intralesional, topical, or oral steroids, cryotherapy, or simple surgical incision or excision biopsy. The most commonly practiced treatment being incision or excision biopsy. ${ }^{1,2,14}$ which was carried in all our cases, with additional mouthwashes and antibiotics in two of them. Recurrence was very uncommon in TUGSE, ${ }^{14}$ however one of our patients had a recurrence 4 months post excision. The sharp tooth was not removed from this patient as she was not willing. This further coincides with the hypothesis of trauma as stated by Velez et al. ${ }^{9}$ The other 3 patients were followed up for a period ranging from 12 months to 42 months with no recurrence.

\section{CONCLUSIONS}

TUGSE is a chronic but self-limiting lesion of the oral mucosa with uncertain pathogenesis, diagnosis of which is made by a combination of clinical details and histomorphology. It may heal spontaneously. An incision or excision biopsy should be done for a definite diagnosis and to exclude malignancy. Causative factors (sharp, fractured, or malpositioned tooth) needs to be corrected with effective follow-up.

\section{Conflict of Interest: None}

\section{REFERENCES}

1. Gnepp DR. Diagnostic Surgical Pathology of the Head and Neck. 2nd ed. Philadelphia: Saunders/Elsevier; 2001.

2. Segura S, Pujol RM. Eosinophilic ulcer of the oral mucosa: a distinct entity or a nonspecific reactive proliferation? Oral dis 2008;14:28795. $\underline{\text { Crossref }}$ 
3. Elzay RP. Traumatic ulcerative granuloma with stromal eosinophilia (Riga- Fede disease and traumatic eosinophilic granuloma). Oral surg Oral Med Oral Pathol 1983;55:497-506. Crossref

4. Taghi A, Motamedi M.K. Riga-Fede disease: A histological study and case report. Indian J Dent Res 2009;20:227-9. $\underline{\text { Crossref }}$

5. Shapiro L, Juhlin EA. Eosinophilic ulcer of the tongue report of two cases and review of the literature. Dermatologica 1970;140:242-50. Crossref

6. Chandra S, Raju S, Sah K, et al. Traumatic ulcerative granuloma with stromal eosinophilia. Arch Iran Med 2014;17:91-4. Crossref

7. Hirshberg A, Amariglio N, Akrish S, et al. Traumatic ulcerative granuloma with stromal eosinophilia: reactive lesion of the oral mucosa. Am J Clin Pathol 2006;126:522-9. Crossref

8. Chavan SS, Reddy P. Traumatic ulcerative eosinophilic granuloma with stromal eosinophilia of tongue. South Asian J Cancer 2013;2:144. Crossref
9. VelezA,AlamillosFJ,DeanA,etal.Eosinophiliculceroftheoralmucosa: reportofarecurrentcaseofthetongue.ClinExpDermatol1997;22:154-6. Crossref

10. Sivapathasundaram B, Lavanya B. Traumatic ulcerative granuloma with stromal eosinophilia (TUGSE). J Oral maxillofac Pathol 2005;9:30-3. Crossref

11. Elovic AE, Gallagher GT, Kabani S, et al. Lack of TGF- $\alpha$ and TGF- $\beta$ synthesis by human eosinophils in chronic oral ulcers. Oral surg Oral Med Oral Pathol Oral Radiol Endod 1996;81:672-81. Crossref

12. El-Mofty SK, Swanson PE, Wick MR, et al. Eosinophilic ulcer of the oral mucosa. Report of 38 new cases with immunohistochemical observations. Oral Surg Oral Med Oral Pathol 1993;75:716-22. Crossref

13. Marszalek A, Neska-Dlugosz I. Traumatic ulcerative granuloma with stromal eosinophilia. A case report and short literature review. Pol J Pathol. 2011;3:172-5. Website

14. Ada S, Seckin D, Tarhan E, et al. Eosinophilic ulcer of the tongue. Australas J Dermatol 2007;48:248-50. Crossref 